\title{
Investigations on Large-Scale Geometric Roughness Elements in Open Channels with Different Heights
}

\author{
Iman A. Alwan ${ }^{*}$, Riyadh Z. Azzubaidi ${ }^{2}$ \\ ${ }^{I}$ Department of water resources engineering, University of Baghdad, Baghdad, Iraq, ïrq979@g-mail.com \\ ${ }^{2}$ Department of water resources engineering, University of Baghdad, Baghdad, Iraq, riyadh.z.azzubaidi@coeng.uobaghdad.edu.iq \\ *Corresponding author: Iman A.Alwan \\ Published online: 31 March 2021
}

Abstract- Large-scale geometric roughness elements is one of the solutions that is used to protect open channels from erosion. It is use to change the hydraulic characteristics of the flow. It may be concrete blocks or large stone placed at the bed of the channel to impose more resistance in the bed. The height of these roughness elements is an important parameter that can affect the hydraulic characteristics of the flow. Using a series of tests of T-shape roughness elements at three different heights, $3,4.5$, and $6 \mathrm{~cm}$, arranged in the fully rough configuration in order to investigate the velocity distributions along the flume. ANSYS Parametric Design Language, APDL, and Computational Fluid Dynamics, CFD, were used to simulate the flow in an open channel with roughness elements. This simulation helps to find the best height of roughness elements that can be used to change the hydraulic characteristics of the flow. The results showed that the velocity values are decreased near the bed by about $61 \%, 58 \%$, and $64 \%$ in case of $3 \mathrm{~cm}, 4.5 \mathrm{~cm}$, and $6 \mathrm{~cm}$ roughness heights consequently compared with the velocity of the control case. The velocity values are increased near the free surface by about $32 \%$ and $19 \%$ in case of roughness elements height $6 \mathrm{~cm}$ compared with $3 \mathrm{~cm}$ and $4.5 \mathrm{~cm}$ roughness heights respectively. The case of $6 \mathrm{~cm}$ roughness height is considered to be the effective case for decreasing the velocity values near the bed of the flume.

Keywords-CFD, Roughness heights, T-Shape, Velocity Distributions.

\section{Introduction}

One of the solutions that is used to control the problem of erosion in open channels is the use of roughness elements to create more resistance in the bed. Many studies were conducted to study the hydrodynamic of open channels flow under the conditions of using roughness elements. [1], found that the velocity magnitude was decreased with increased roughness height in the western side of Shatt alArab and increased in the other side. Bora and Misra, [4], studied the effect of flexible vegetation and rigid by using PVC wires and bending it according to requirements. The study was provided different heights of wires to present like vegetation in open channels. Roughness coefficient was decreased with increased flow depth. The rigid one had more resistance than flexible one under the same flow condition. Roughness coefficient was decreased by increasing the vegetation flexibility. Thappeta, et al., [5] investigated the effect of using hemisphere boulders and cylindrical roughness elements constructed in a staggered distribution in a steep open channel by using CFD software. The energy loss was decreased as the density of the boulders was increased. The energy loss was depended on Froude number, relative submergence, density and the distance from the upstream to the test section. Mulahasan in [6], who used cylindrical roughness elements with different diameters. He aimed to obtain the effect of vegetated flood-plain in open channels. For large diameter of rods, the depth of water rise quickly above the rods. Wang et al., [7] used five sediment roughness different in diameters and was found that the velocity distribution depends on the roughness scale and flow conditions. The velocity with $\mathrm{S}$-shape profile was appeared instead of the logarithmic velocity profile for cases with high velocity flows and big bottom roughness scale. 
This study aimed at investigating the effect of using Tshape roughness elements with different heights on the velocity distribution and energy dissipation.

In this study, regular roughness elements in the shape were placed with a staggered configuration in the flume bed. APDL and CFD programs used to simulate the flow through the roughened flume. ANSYS CFD solves mathematically the Navier-Stokes and continuity equations. The standard $\mathrm{k}-\omega$ model prepares accurate solution. There is a proving version of $\mathrm{k}-\omega$ model named SST $\mathrm{k}-\omega$.

\section{Description of the Case Study}

To investigate flowing water in open channels with roughness elements by using the CFD software, using mechanical APDL product launcher (ANSYS Parametric Design Language). The simulation was conducted in a flume of $0.35 \mathrm{~m}$ depth, $0.3 \mathrm{~m}$ width, and a length of $5 \mathrm{~m}$ at 0.001 slope. Geometric roughness element of T-shape was used with base $3^{*} 3 \mathrm{~cm}^{2}$ and different heights $3 \mathrm{~cm}, 4.5 \mathrm{~cm}$, and $6 \mathrm{~cm}$ as shown in Figure 1. This type of roughness element was used by Ghazal, [2] in his experimental study. The test section within the flume is of $1 * 0.3 \mathrm{~m}^{2}$ located at the center of the flume to place the roughness elements in a staggered pattern. The staggered pattern is of distance include rows and columns. The distance between rows is $10.78 \mathrm{~cm}$ and between columns is $6 \mathrm{~cm}$ from center to center of elements as a fully rough configuration, Figure 2. One discharge of $5.8 \mathrm{l} / \mathrm{s}$ is applied in the investigation. The used corresponding water depth to this discharge at the downstream end of the flume is $0.1 \mathrm{~m}$.

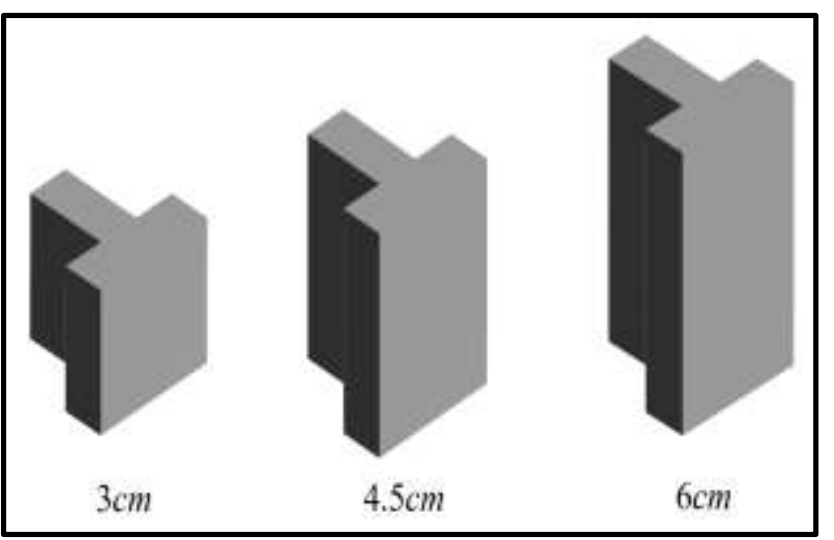

Figure 1: T-shape roughness elements at different heights

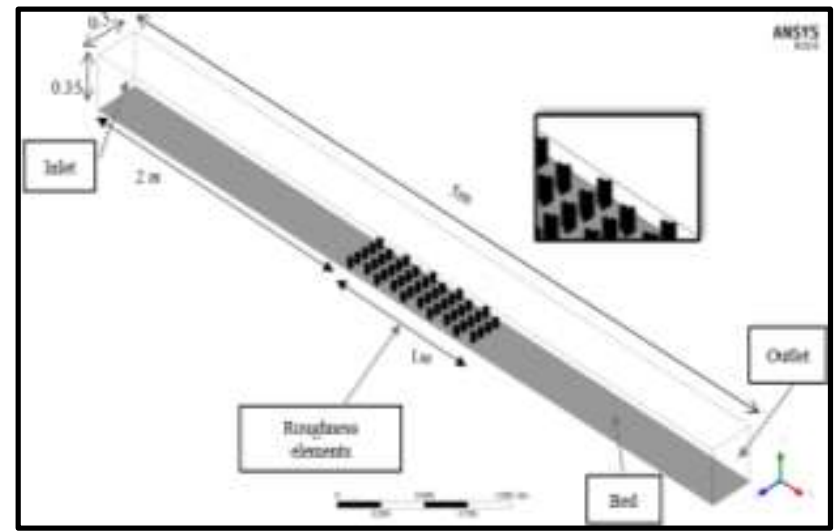

Figure 2: The geometry of the study

\section{Design of Models Runs}

To conduct runs by using with a computational fluid dynamics CFD program (FLUENT), various options used in this simulation, transient flow, volume of fluid, multiphase flow (air and water), PISO method (pressureimplicit splitting of operators) and K-omega -SST (shear stress transport). The $\mathrm{k}-\varepsilon$ model is more suitable in regions far from the boundaries, wall. Near wall boundary zones, the standard $\mathrm{k}$ - $\omega$ model prepares more accurate solution. ANSYS CFD solves mathematically the NavierStokes and continuity Equations (1) and (2).

$\rho \frac{D V}{D t}=-\nabla P+\rho g+\mu \nabla^{2} V$

(1)

$\frac{\partial u i}{\partial x j}=0$

Where:

$V=$ component of the Reynolds average velocity $(\mathrm{m} / \mathrm{s})$,

$\mathrm{t}=$ time $(\mathrm{s})$,

$\rho=$ density of fluid $\left(\mathrm{kg} / \mathrm{m}^{3}\right)$,

$P=$ Reynolds average pressure $\left(\mathrm{kn} / \mathrm{m}^{2}\right)$,

$\mathrm{g}=$ acceleration due to gravity $\left(\mathrm{m} / \mathrm{s}^{2}\right)$,

$\mu=\operatorname{viscosity~}(\mathrm{kg} / \mathrm{m} . \mathrm{s})$,

$u i=i$-th component of the Reynolds average velocity, $x j=i-t h$ axis.

The boundary conditions were defined as mass flow inlet and pressure outlet, [3]. Velocity of air above water surface was set to zero as initial boundary condition. One variable was taken into consideration in the run to simulate the flow is the height of the roughness elements in the test section. One depth of $0.1 \mathrm{~m}$ was applied at the inlet of the flume. The corresponding discharge to this depth is $5.8 \mathrm{l} / \mathrm{s}$. 
Table 1 descripts the design of simulation runs. Four runs were conducted, the first run was conducted without any roughness elements placed in the flume for comparison purposes. The other three was conducted with roughness height, $3 \mathrm{~cm}, 4.5 \mathrm{~cm}$, and $6 \mathrm{~cm}$.

Table 1: Design of runs.

\begin{tabular}{|c|c|}
\hline Height of roughness elements $\mathrm{cm}$ & Run number \\
\hline without & 1 \\
\hline 3 & 2 \\
\hline 4.5 & 3 \\
\hline 6 & 4 \\
\hline
\end{tabular}

\section{Results and Analysis}

Figure 3 and Figures A-1, A-2, A-3 (Appendix A) present the directions and the values of the flow velocity profiles as contours within the flow in the flume in cases of without roughness elements, $3 \mathrm{~cm}, 4.5 \mathrm{~cm}$ and $6 \mathrm{~cm}$ roughness heights under the same flow conditions.

In case of without elements, the profiles of velocity are not affected along the flow domain because there is no change in the cross section of the flume. The velocity magnitude is $0.18 \mathrm{~m} / \mathrm{s}$ in the horizontal plane at $1.5 \mathrm{~cm}$ from the bed, $0.19 \mathrm{~m} / \mathrm{s}$ in a plane at $2.25 \mathrm{~cm}$ from the bed, $0.196 \mathrm{~m} / \mathrm{s}$ in a plane $3 \mathrm{~cm}$ from the bed, $0.214 \mathrm{~m} / \mathrm{s}$ in a plane at $4.5 \mathrm{~cm}$ from the bed, $0.218 \mathrm{~m} / \mathrm{s}$ in a plane at $6 \mathrm{~cm}$ from the bed and have a maximum velocity of about $0.22 \mathrm{~m} / \mathrm{s}$ in a plane $15 \mathrm{~cm}$ from left side of the channel, Figure 3.

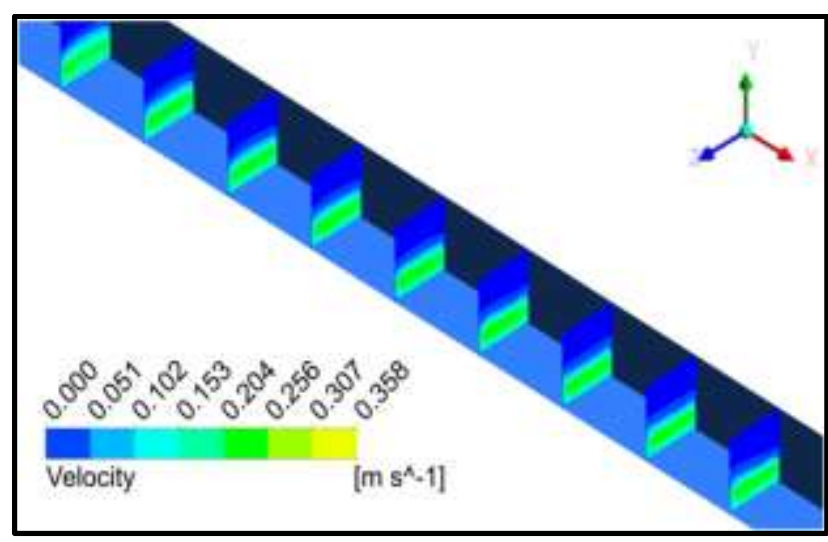

Figure 3: Velocity profiles in a flume without roughness elements

In case of $3 \mathrm{~cm}$ roughness height, at mid height of the roughness elements, the velocity value is $0.07 \mathrm{~m} / \mathrm{s}$. At top surface of the roughness elements, the velocity value is $0.16 \mathrm{~m} / \mathrm{s}$. At the cross section along the flume, the velocity value is $0.29 \mathrm{~m} / \mathrm{s}$, Figure A-1 (Appendix A).

In case of $4.5 \mathrm{~cm}$ roughness height, the velocity values at location at mid height of the roughness elements is $0.08 \mathrm{~m} / \mathrm{s}$. At top surface of the roughness elements, the velocity values is $0.18 \mathrm{~m} / \mathrm{s}$. At the cross section along the flume, the velocity values is $0.32 \mathrm{~m} / \mathrm{s}$, Figure A-2 (Appendix A).

In case of roughness height $6 \mathrm{~cm}$, at mid height of the roughness elements, the velocity values is $0.07 \mathrm{~m} / \mathrm{s}$. At top surface of the roughness elements, the velocity values is $0.23 \mathrm{~m} / \mathrm{s}$. At the cross section along the flume, the velocity values is $0.36 \mathrm{~m} / \mathrm{s}$, Figure A-3 (Appendix A).

As a comparison between cases, Figures A-4, A-5, A-6 (Appendix A) presents the results includes figures shows the effects of applying roughness elements in the flume. These figures includes the variation of the velocity profiles present by contours within the flow domain in the flume for different height of roughness elements comparison with the control case. Figure 4 to Figure 6 includes the variation of velocity with water depth comparing between cases for different heights of roughness elements and with the control case at the center of the flume.

Generally, velocity distributions in the fluid domain are affected by increasing the heights of the roughness elements. At mid height of the roughness elements, the velocity values decreased in case of $3 \mathrm{~cm}, 4.5 \mathrm{~cm}$ and $6 \mathrm{~cm}$ roughness heights by about $61 \%, 58 \%, 64 \%$ consequently of the velocity of the control case. At top surface of the roughness elements, the velocity values decreased in case of $3 \mathrm{~cm}$ and $4.5 \mathrm{~cm}$ roughness heights by about $18 \%$ and $16 \%$ and increased by about $6 \%$ of the velocity of the control case in case of $6 \mathrm{~cm}$ roughness height. In the longitudinal cross sections, we can notice the low velocity of water in the zone near the roughness elements and it will increase till reaching the water surface. Along the center of the flume, the velocity values increased above the roughness elements in case of $3 \mathrm{~cm}, 4.5 \mathrm{~cm}$ and $6 \mathrm{~cm}$ roughness heights by about $32 \%, 45 \%, 64 \%$ consequently of the maximum velocity of the control case.

At mid height of the roughness elements, the velocity values decreased in $6 \mathrm{~cm}$ roughness height by about $3 \%$ and $6 \%$ compared with $3 \mathrm{~cm}$ and $4.5 \mathrm{~cm}$ roughness heights. Moreover, there was a reverse flow directly in front of the elements due to the effect of the impact of water. At the top surface of the roughness elements, the velocity values increased in case of $6 \mathrm{~cm}$ roughness height by about $6 \%$ compared with the velocity of the control case and decreased in case of $3 \mathrm{~cm}$ roughness height by about $2 \%$ compared with $4.5 \mathrm{~cm}$ roughness height. At the center of the side view along the flume, the velocity values increased above the roughness elements in case of $6 \mathrm{~cm}$ roughness height by about $32 \%$ and $19 \%$ compared with $3 \mathrm{~cm}$ and $4.5 \mathrm{~cm}$ roughness heights. Figure 4 to Figure 6 showed that the velocity values decreased at the center much more than the sides of the flume due to the effect of roughness elements and the smoothness of the side walls. 


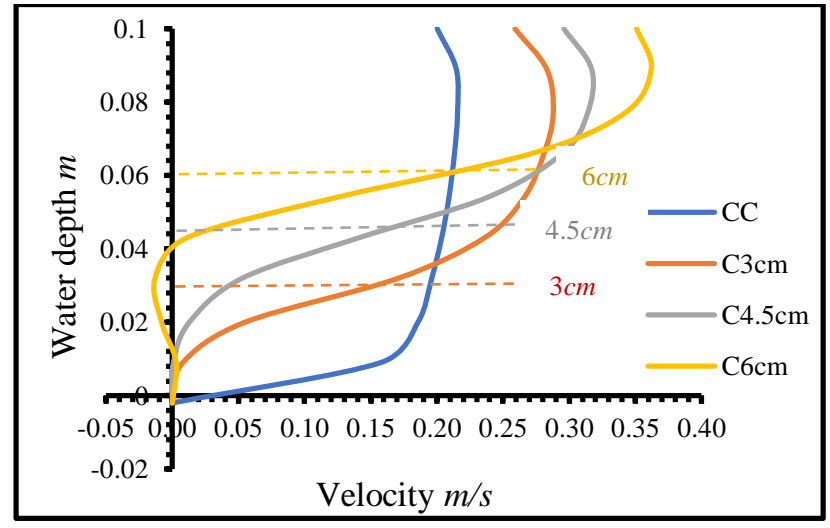

Figure 4: Velocity-water depth relationship at the center of the cross section.

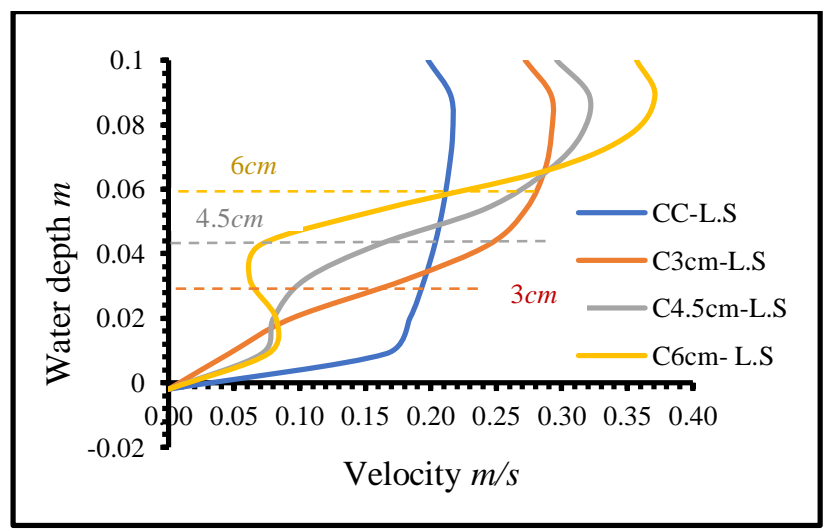

Figure 5: Velocity-water depth relationship at the left side of the flume.

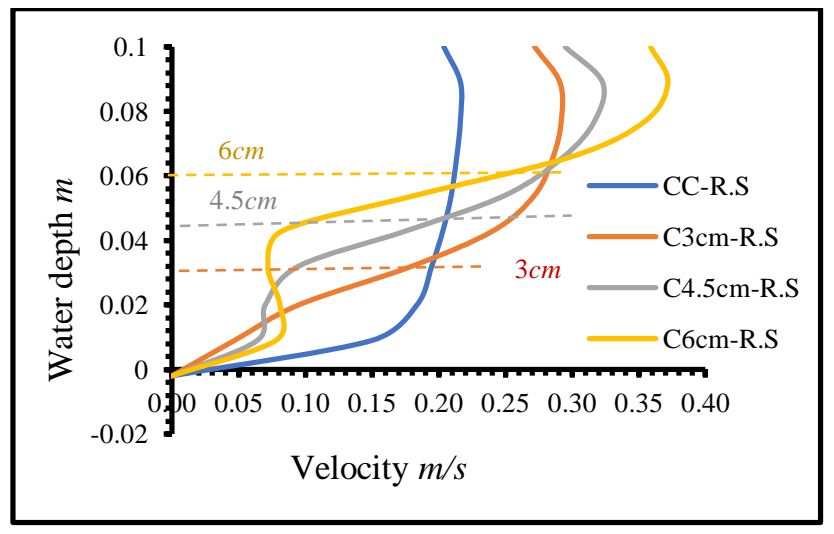

Figure 6: Velocity-water depth relationship at the right side of the flume.

\section{Conclusions}

This research aimed at studying the velocity distributions along the flume with different heights of roughness elements in order to preset details of a suggested about which height of roughness elements is better to use as energy dissipater.

Velocity values were decreased near the bed in case of $6 \mathrm{~cm}$ roughness height much more than other roughness heights by about $3 \%$ and $6 \%$ compared with $3 \mathrm{~cm}$ and $4.5 \mathrm{~cm}$ roughness heights. There was a reverse flow directly in front of the elements in case of $6 \mathrm{~cm}$ roughness height due to the effect of the impact of water. On the contrary of that, the velocity values increased above the roughness elements in case of $6 \mathrm{~cm}$ roughness height and had the maximum velocity near the free surface by about $32 \%$ and $19 \%$ compared with $3 \mathrm{~cm}$ and $4.5 \mathrm{~cm}$ roughness heights. That's will give us indicate that is case of $6 \mathrm{~cm}$ roughness height is more effected in decreasing the velocity than other cases. The velocity values decreased at the center much more than the sides of the flume due to the effect of roughness elements and the smoothness of the side walls.

\section{Recommendations}

For future studies the main recommendations are using another shapes, heights with different configurations. Investigate the effects of using roughness elements in channels bends.

\section{Acknowledgements}

A great acknowledgement to all professors and the staff members of the Department of Water Recourses Engineering in the College of Engineering at University of Baghdad.

\section{Symbols}

$\begin{array}{ll}k & \text { Turbulent kinetic energy } \\ \omega & \text { Specific dissipation rate } \\ \varepsilon & \text { specific dissipation }\end{array}$

\section{Abbreviations}

APDL ANSYS Parametric Design Language

CFD Computational Fluid Dynamics

L.S. Left Side

PISO Pressure Implicit with Splitting of

R S. Operators

R.S. Right Side

SST Shear Stress Transport

VOF Volume of Fluid 


\section{Appendix A}

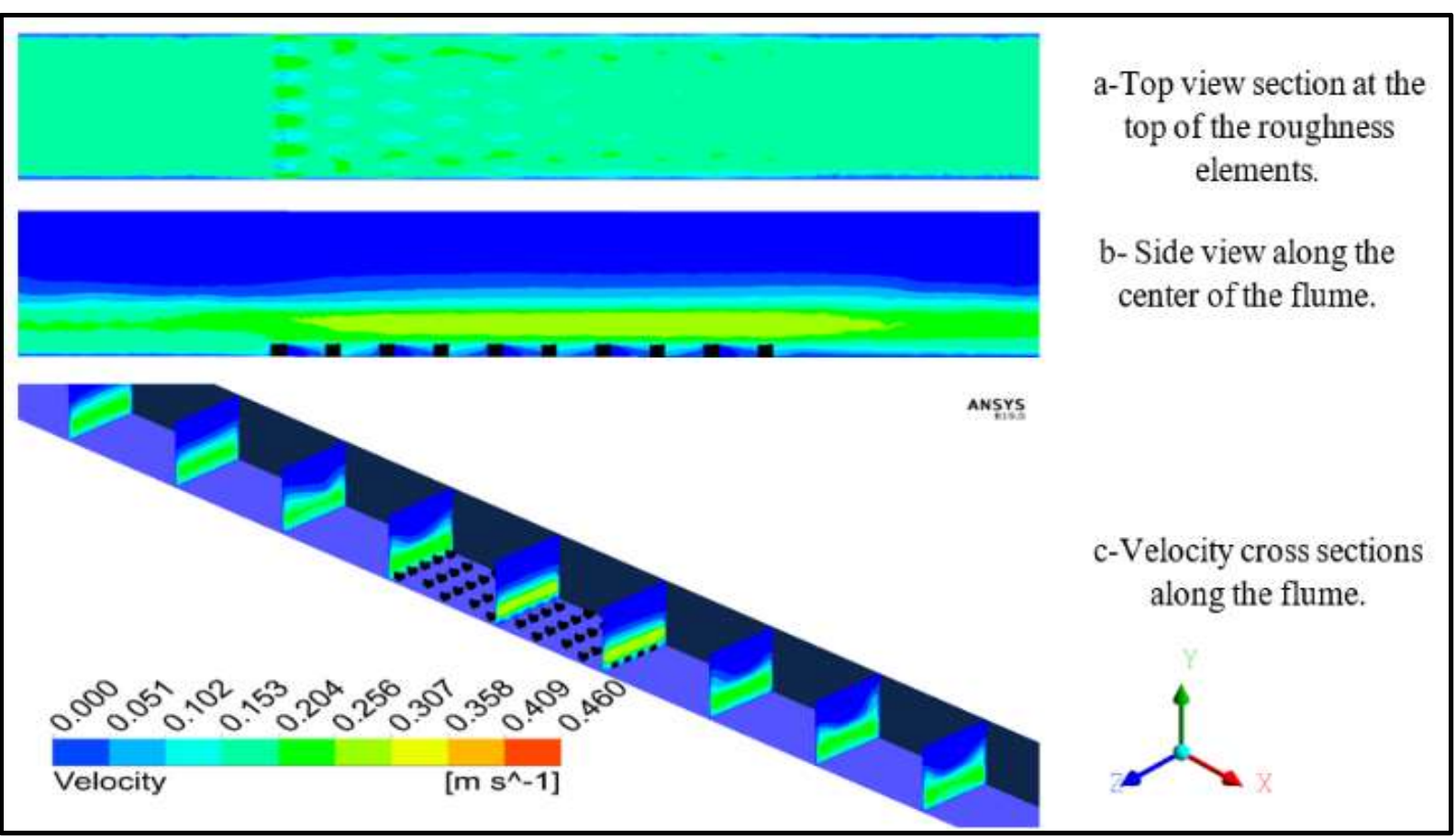

Figure A-1: Velocity profiles in case of $3 \mathrm{~cm}$ roughness height.

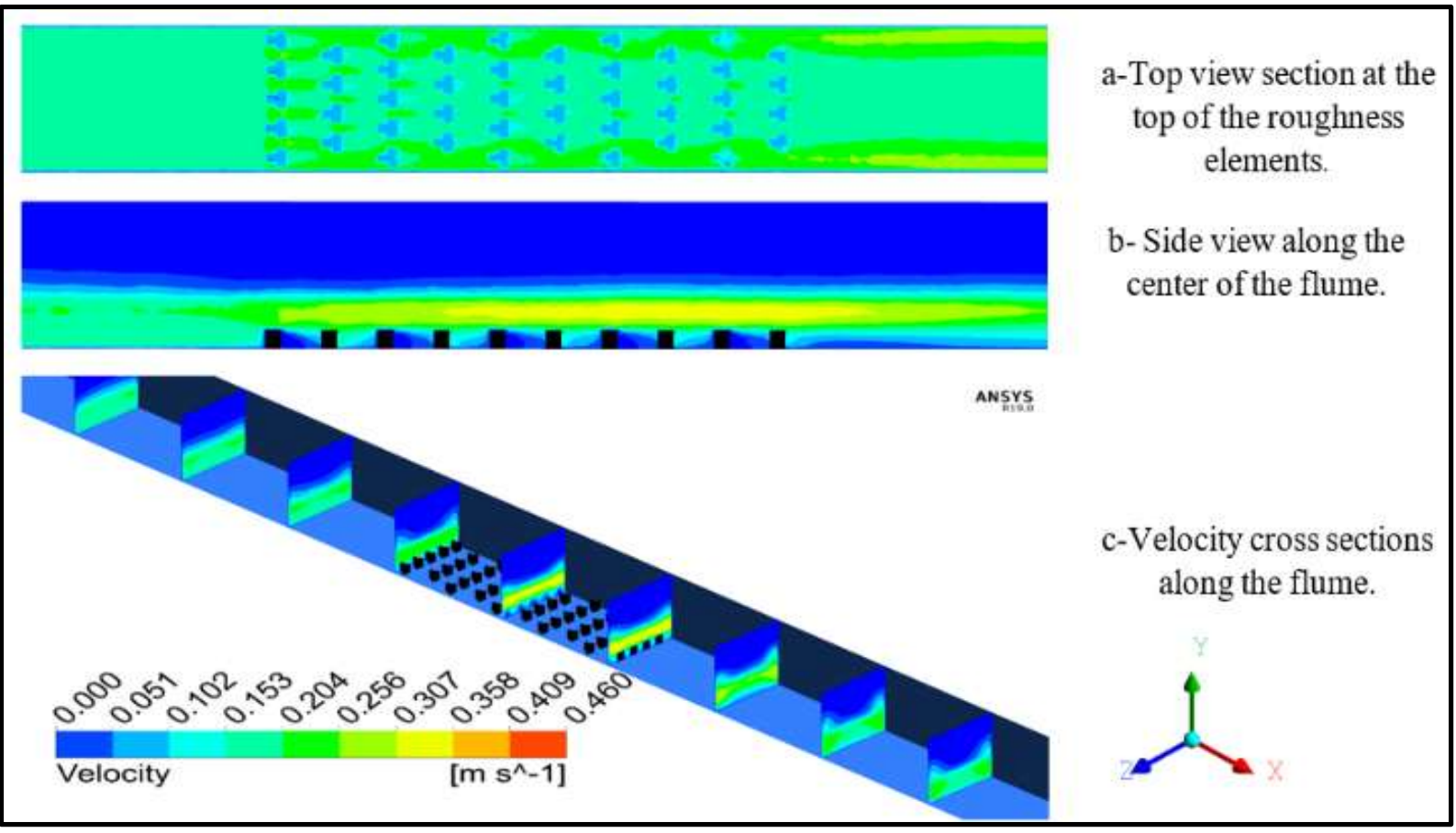

Figure A-2: Velocity profiles in case of $4.5 \mathrm{~cm}$ roughness height. 


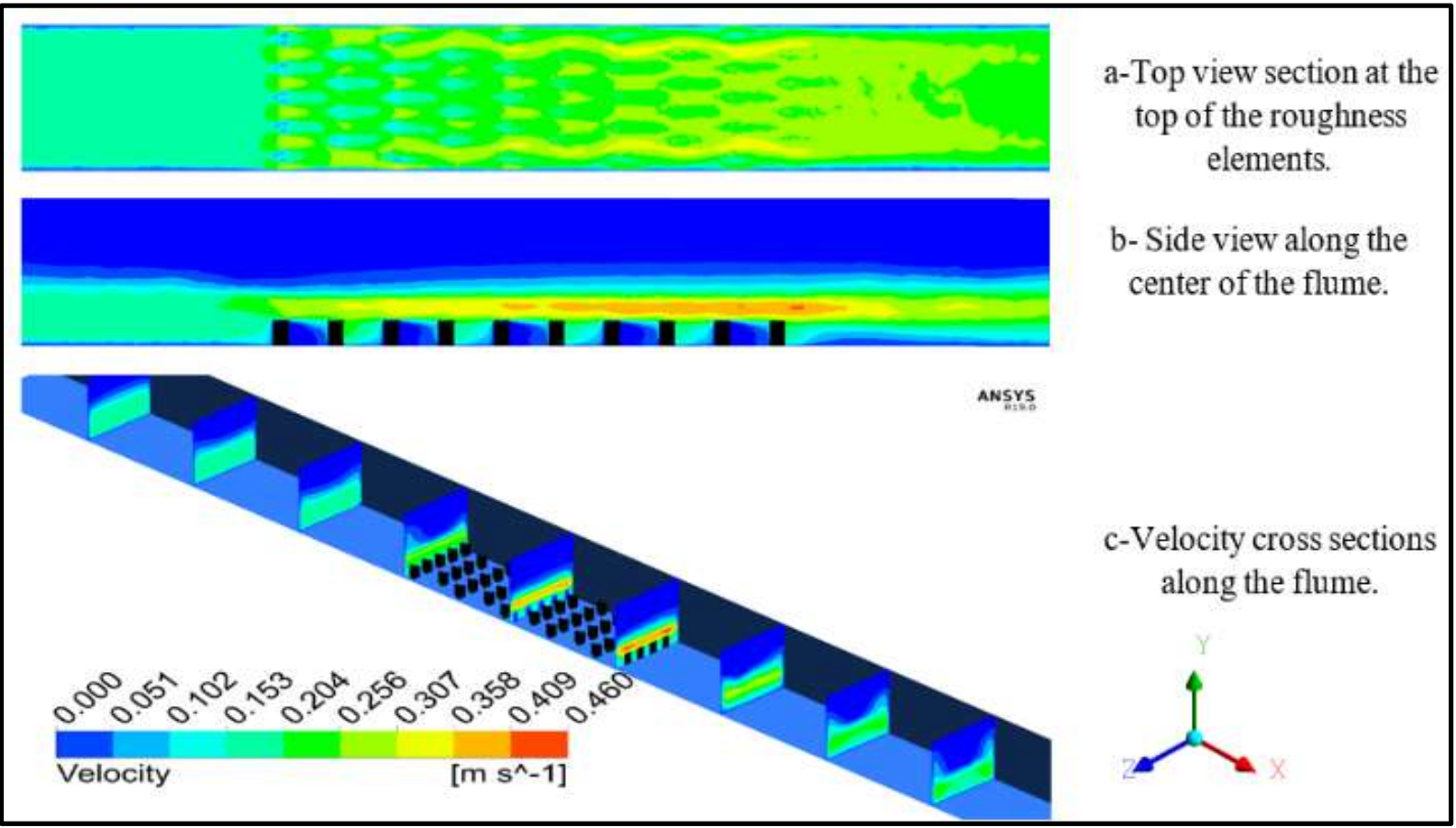

Figure A-3: Velocity profiles in case of $6 \mathrm{~cm}$ roughness height.

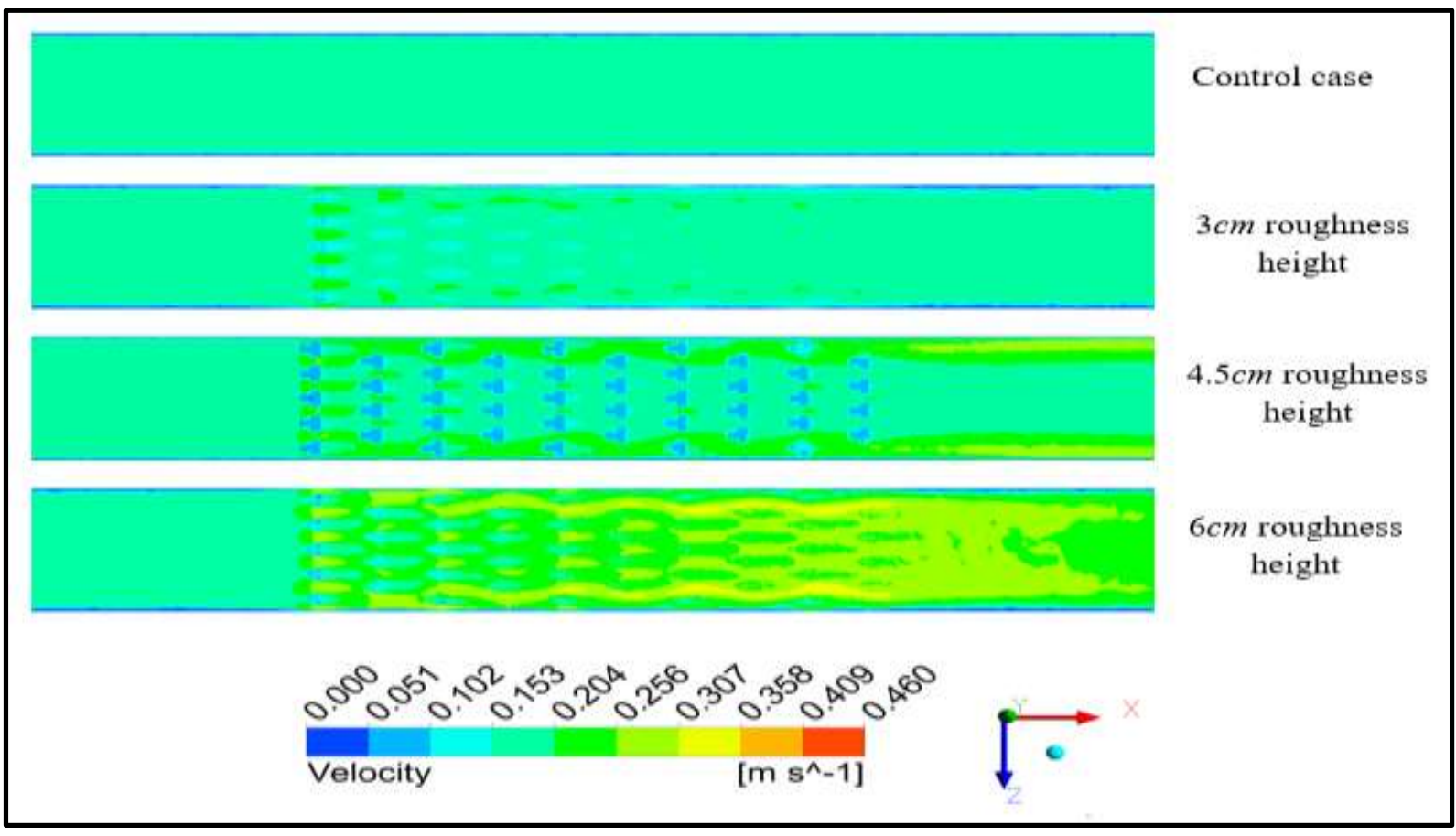

Figure A-4: Top view section at the top of the roughness elements. 


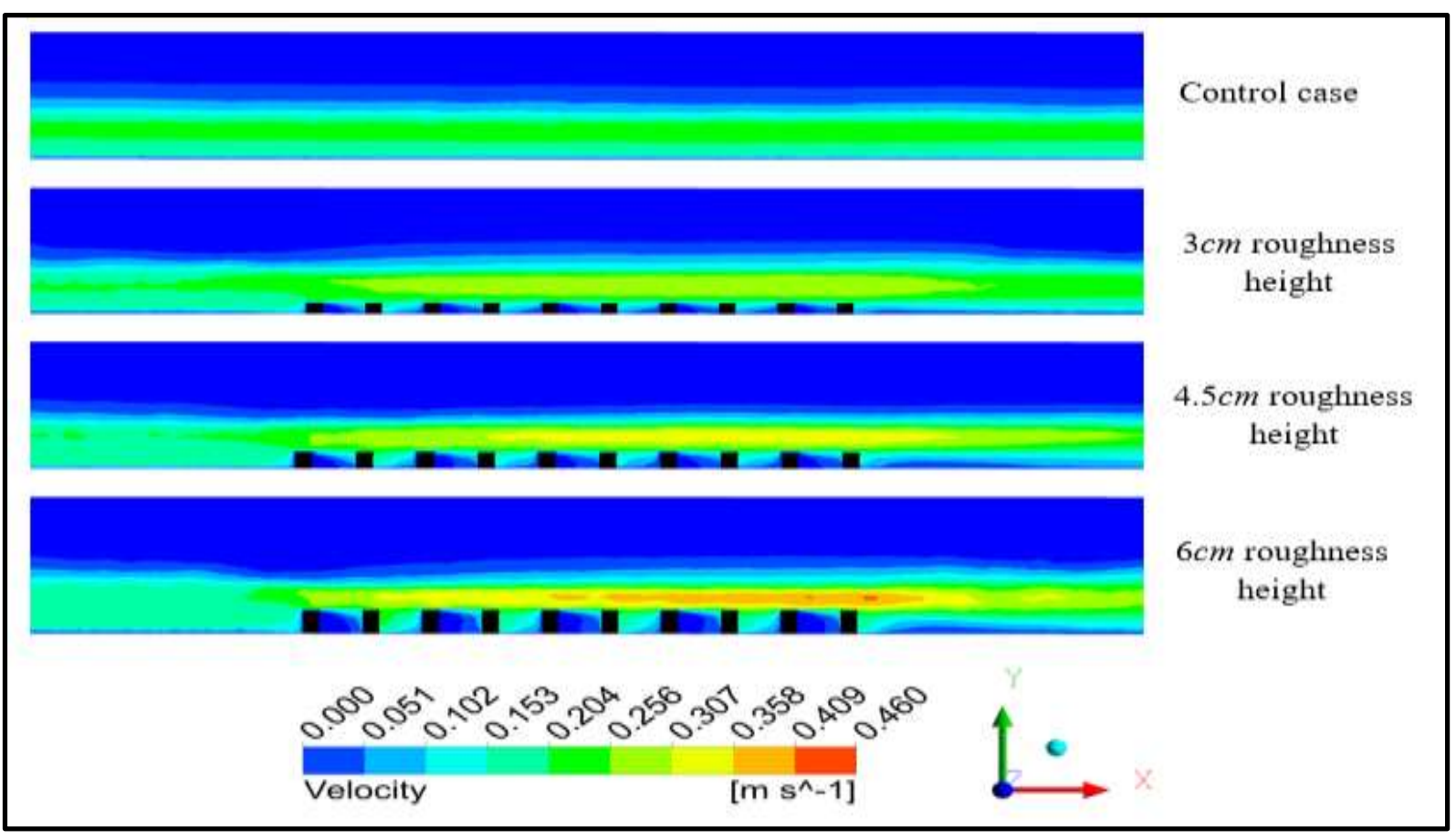

Figure A-5: Side view along the center of the flume.

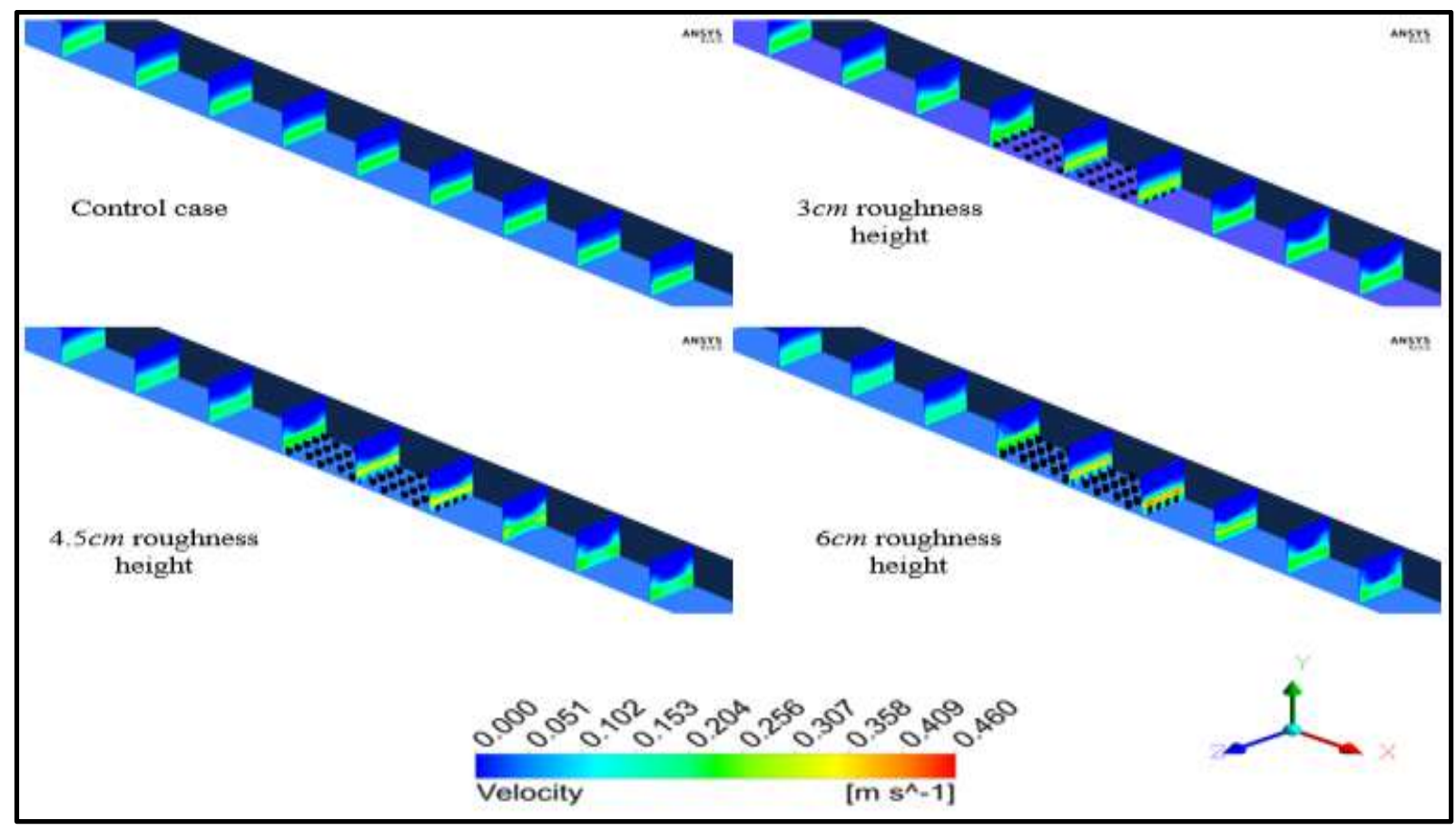

Figure A-6: Velocity cross sections along the flume. 


\section{References}

[1]. Abbas, A. M., Mohammed, A. Y., 2020, Roughness Effect on Velocity Distribution in Selected Reach of Shatt al-Arab River, Journal of Engineering, vol.26, No. 8, pp. 46-58, 2020.

[2]. A. Ghazal, "Manning's Coefficient for Geometric Roughness Elements," M. Sc. thesis, University of Baghdad - College of Engineering, 2015.

[3]. ANSYS Fluent Theory Guide 19.0 Release.

[4]. P. Bora, U. Misra,-“An Experimental Study on Effect of Flexibility of Vegetation on Resistance to Flow," International Research Journal of Engineering and Technology (IRJET), vol. 5, Issue 2, 2018.

[5]. S. K. Thappeta, S. M. Bhallamudi, F. Fiener, B. Narasimhan, "Resistance in Steep Open Channels Due to Randomly Distributed Macro Roughness Elements at Large Froude Numbers," Journal of Hydraulic Engineering, vol.22, Issue 12,2017.
[6]. S. Mulahasan, "Hydrodynamics of Large Scale Roughness in Open Channels," Ph.D. thesis, Division of Civil Engineering, Cardiff School of Engineering, Cardiff University, 2016.

[7]. X. Wang, C. Ye, B. Wang, X. Yan, "Experimental Study on Velocity Profiles with Different Roughness Elements in a Flume", Acta Geophysica, vol.63, No. 6, pp. 1685-1705, 2015.

\title{
التحري باستخدام ارتفاعات مختلفة لوحدات خشونة ذات حجم هندسي كبير في القتوات المفتوحة
}

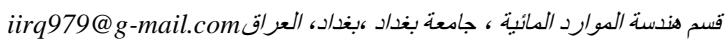

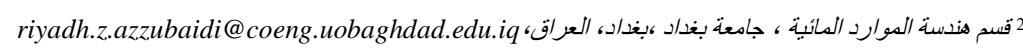 \\ "الباحث المعثل: أبيان عبد السلام علوان

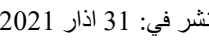

الخلاصة ــ إحدى الحلول المستخدمة لحماية القنو ات المفتوحة من التعرية في مقاطع محددة على امتداد المجاري المائية هي استخدام عناصر

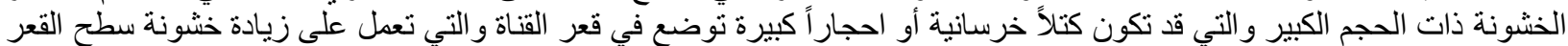

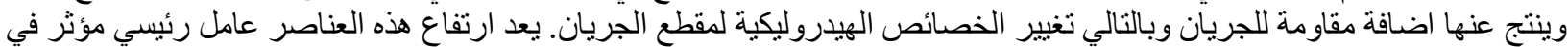

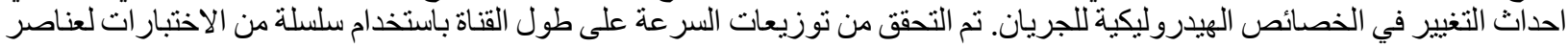

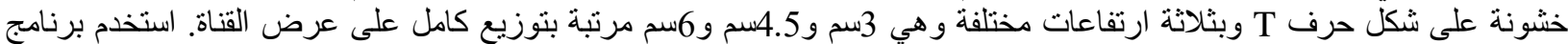
ووبرنامج Computational Fluid Dynamics لمحاكاة جريان الماء خلاء القناة المفتوحة بوجود عناصر الخشونة. استخدمت هذه التجارب العددية وذلك لإيجاد أفضل ارتفاع لعناصر الخشونة يستخدم في تغيير الخصائص

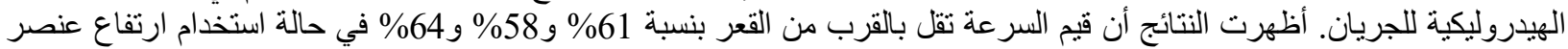

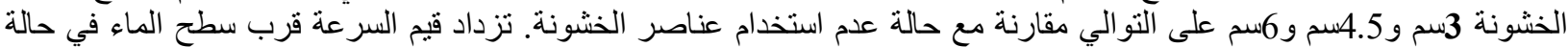
استخدام ارتفاع عنصر الخشونة 6سم وذلك بنسبة 32\% و 19\% مقارنة مع 3سم و 4.5سم. أعنبر أن ارتفاع عنصر الخشونة 6سم هو الاكثر فعالية في تقليل السرعة بالقرب من قعر القناة.

$$
\text { الكلمات الرئيسية _- حسابات ديناميكية الموائع ، ارتفاع الخشونة ، T-shape ، توزيع السر عة ". }
$$

